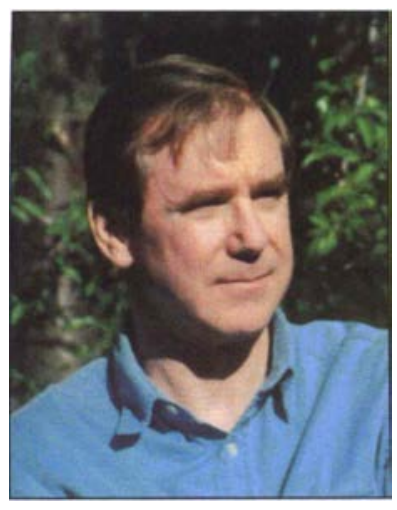

\title{
New negotiations hold trade opportunities for agriculture
}

DANIEL A. SUMNER

Director

Agricultural Issues Center

$\mathrm{S}$ ince Adam Smith published The Wealth of Nations, economists have had a clear set of answers to questions about international trade policy. Open borders are good for producers in exporting nations, for consumers in importing nations, for each economy individually, and for the world economy overall. In virtually every practical case, removing trade barriers contributes to economic well-being. Elaboration of theory and evidence in the past 223 years have added refinements and caveats to Smith's basic points, but the thrust of the argument has not changed.

With a new round of world trade negotiations beginning this fall, it is time to consider the effects of alternative trade policies for agriculture and the rest of the economy. Both the United States as a whole, and California more specifically, are natural agricultural exporters of many farm products. In fact, although El Niño and the Asian financial crisis both reduced exports last year, figures recently released by the Agricultural Issues Center (AIC) show that California agriculture still accounted for almost $\$ 7$ billion in 1998 exports. Almonds, cotton and wine remain the top export earners and Asia remains the top destination. For California, the special trade interests of agriculture and the general interests of the U.S. economy overlap.

Studies at the AIC, such as those dealing with dairy and processing tomato policies, as well as studies done elsewhere will help us understand implications of alternative trade policies. But Smith's basic point applies. Open agricultural markets would be good for the California economy (just as they would be for Japan and Korea) even if California were a net importer of farm goods. Remember also that more than $80 \%$ of California farm output is sold in the United States. Therefore, when we consider what features of trade agreements are good for agriculture, we must not neglect the importance of liberal trade to U.S. economic growth and growth elsewhere.

The Uruguay Round of the General Agreement on Tariffs and Trade (GATT) created the World Trade Organization (WTO) in 1995. It began a gradual liberalization of agricultural markets. The agreement generally eliminated absolute import bans and replaced import quotas with tariffs (often quite high). However, the agreement also called for reductions in agricultural tariffs and export subsidies, on average $6 \%$ annually until 2001, for the rich WTO members. If the pace were allowed to continue without delay, agricultural tariffs and export subsidies in WTO member countries would be zero by Sept. 1, 2011. The world would have (almost) free trade in agriculture.
The Uruguay Round took 8 years to complete, so, by the end, some thought "GATT" stood for the "General Agreement to Talk and Talk." The greatest risk in the new round is the delay in further reform caused by another round of seemingly endless negotiations.

One landmark of the Uruguay round was the agreement that Sanitary and Phytosanitary (SPS) regulations must be scientifically sound. Unless countries have reasonable scientific backing for SPS trade restrictions, they must remove the restrictions or compensate their trade partners.

Every nation and region has vital and legitimate interests in protection against human, animal and plant health risks. (Indeed, AIC has a major project under way on how to improve such policies for the United States and California.) That said, phony trade barriers can easily hide behind such legitimate concerns, and the requirement that countries have a sound scientific basis for SPS rules was designed to help weed out these phony barriers.

While a number of complex issues remain to be adjudicated in this area, for example the impact of genetically modified organisms, these issues are not a reason to reopen negotiations on the SPS agreement itself.

Food security (access to adequate nutrition by all individuals) is one of the most commonly stated rationales for trade barriers in agriculture. But potentially tragic consequences of such barriers have been demonstrated by the famine gripping isolationist North Korea. By contrast, the city-states of Hong Kong and Singapore, which produce virtually no food, have made remarkable gains in providing adequate nutrition for their populations by simply allowing unrestricted access to international markets.

Nevertheless, countries as diverse as South Korea, the United States and Switzerland continue to use food security arguments to justify trade barriers. One argument is that international markets are "unstable" or "unreliable." This is a concern that the WTO could help alleviate. Importers have a strong and legitimate case that the WTO should explicitly and clearly ban the use of export taxes and embargoes in agriculture. Such a provision would help make world food markets more secure for all.

The upcoming round of trade negotiations in agriculture can build on the foundation established in the Uruguay Round agreement. Whether or not that occurs, the results are like to be important for California agriculture and the world economy as a whole. 